\title{
Autoimmune response following influenza H1N1 vaccination in patients with juvenile idiopathic arthritis
}

\author{
Nadia E Aikawa', Claudia Goldenstein-Schainberg ${ }^{1 *}$, M Vendramini $^{1}$, Lucia MA Campos ${ }^{1}$, Carla G Saad ${ }^{1}$, \\ Julio B Moraes ${ }^{1}$, Alberto Duarte ${ }^{1}$, Alex R Precioso ${ }^{3}$, Maria CST Timenetsky², E Bonfá', Clovis A Silva ${ }^{1}$ \\ From 18th Pediatric Rheumatology European Society (PReS) Congress \\ Bruges, Belgium. 14-18 September 2011
}

\section{Background}

To assess autoimmune response and H1N1 serology following influenza $\mathrm{H} 1 \mathrm{~N} 1$ vaccination in juvenile idiopathic arthritis (JIA).

\section{Methods}

58 JIA patients were vaccinated with cepa A/California/ 7/2009 (NYMC X-179A) anti-H1N1. All participants received 1 dose of immunization, those $<9 \mathrm{yrs}$ of age received a second dose 3 weeks apart. All sera were evaluated before and 3weeks after complete vaccination. Serology against H1N1 virus was performed by hemagglutination inhibition antibody assay, antinuclear antibodies (ANA) by IIF, IgM and IgG anticardiolipin (aCL) by ELISA, and rheumatoid factor (RF) by latex fixation test.

\section{Results}

Mean age of patients $=23.9 \pm 9.5 \mathrm{yrs}, 38 \mathrm{~F}: 20 \mathrm{M}$, mean disease duration $=14.7 \pm 10.1 \mathrm{yrs}$. Six $(10 \%)$ had systemic, 33 (57\%) poliarticular, $10(17 \%)$ oligoarticular and $9(16 \%)$ other JIA subtype. Sixteen were off drugs and $42(72 \%)$ under different drug treatments: $32(55 \%)$ using one DMARD/IS, 10(17\%) on 2 DMARDs/IS, 19(33\%) antimalarials, 29(50\%) MTX, 8(14\%) sulfasalazine, 6(10\%) anti-TNFs, 4(7\%) abatacept; no patient was using prednisone $>0.5 \mathrm{mg} / \mathrm{kg} / \mathrm{d}$. Seroprotection rates against H1N1 influenza increased from 23 to $83 \%$ and seroconversion rates were achieved in 78\% JIA. Before vaccination 31(53.4\%) of JIA patients were positive for ANA, 6 (10.3\%) for RF, and 4(7\%) for both IgM and IgG aCL.
After complete H1N1 vaccination, positivity for ANA remained the same whereas one patient became negative for IgG aCL, and another for RF, IgM and IgG aCL. Only $1 / 58(1.7 \%)$ patient turned positive for low titer IgG aCL.

\section{Conclusions}

Except for 1 patient that became positive for low titer IgG aCL, vaccination of JIA patients against pandemic influenza A (H1N1) generated successful protective antibody production with short term safety profile.

\section{Author details}

${ }^{1}$ Rheumatology, Universidade de Sao Paulo, São Paulo, SP, Brazil. ${ }^{2}$ Adolpho Lutz Institute, Universidade de Sao Paulo, São Paulo, SP, Brazil. ${ }^{3}$ Butantan Institute, São Paulo, SP, Brazil.

Published: 14 September 2011

doi:10.1186/1546-0096-9-S1-P133

Cite this article as: Aikawa et al:: Autoimmune response following influenza H1N1 vaccination in patients with juvenile idiopathic arthritis. Pediatric Rheumatology 2011 9(Suppl 1):P133.

\footnotetext{
* Correspondence: cgs@usp.br

${ }^{1}$ Rheumatology, Universidade de Sao Paulo, São Paulo, SP, Brazil

Full list of author information is available at the end of the article
}

(C) 2011 Aikawa et al; licensee BioMed Central Ltd. This is an open access article distributed under the terms of the Creative Commons Attribution License (http://creativecommons.org/licenses/by/2.0), which permits unrestricted use, distribution, and reproduction in any medium, provided the original work is properly cited. 